\title{
The assessment of early and late gestational termination cases
}

\author{
Serdar Kaya¹ (iD), Ferdi Vaizoğlu² (iD), Sezin Yakut Uzuner³ (D), Havva Serap Toru ${ }^{4}$, \\ Mehmet Şimşek ${ }^{5}$ iD), Selahattin Kumrư \\ ${ }^{1}$ Department of Perinatology, Clinics of Gynecology and Obstetrics, Bağcllar Training and Research Hospital, Health Sciences University, Istanbul, Turkey \\ ${ }^{2}$ Department of Gynecological Oncology, Clinics of Gynecology and Obstetrics, Kanuni Sultan Siileyman Training and Research Hospital, \\ Health Sciences University, Istanbul, Turkey \\ ${ }^{3}$ Department of Medical Biology, Faculty of Medicine, Akdeniz University, Antalya, Turkey \\ ${ }^{4}$ Department of Medical Pathology, Faculty of Medicine, Akdeniz University, Antalya, Turkey \\ ${ }^{5}$ Perinatology Clinic, Department of Gynecology and Obstetrics, Faculty of Medicine, Akdeniz University, Antalya, Turkey
}

\begin{abstract}
Objective: We aimed to investigate the characteristics of early and late gestational termination cases by evaluating the cases underwent gestational termination in our clinic.

Methods: All pregnant women who had singleton pregnancy and underwent gestational termination due to fetal indications between January 2017 and December 2019 were included in the study.

Results: A total of 341 cases, of which 263 were with early gestational termination (Group 1) and 73 were with late gestational termination (Group 2) were included in the study. No difference was observed between the demographic characteristics of the groups. The ultrasonographic structural anomaly was observed in $273(80.1 \%)$ of 341 cases and no structural anomaly was observed in $68(19.9 \%)$ cases. Of the cases with structural anomaly, $200(73 \%)$ had isolated system anomaly and 73 (26.7\%) had multiple system anomaly. Karyotype analysis was performed in $68 \%$ of the cases, and chromosomal anomaly was found in $52.6 \%$ of them. Among the cases with normal karyotype analysis results, 22 cases had single gene disorder, of which mostly had thalassemia. While the incidence of structural anomaly was significantly high in the late termination cases (91\% vs. $76.8 \%)$, the incidence of isolated cardiovascular anomaly was significantly high in the late termination cases similarly $(37.5 \%$ vs. $13.8 \%)$. The autopsy was performed on $16.7 \%$ of the cases after termination and the findings were consistent with the prenatal ultrasonographic results in $86 \%$ of the cases, and additional findings were found in $22.4 \%$ of the cases in the autopsy.

Conclusion: When the late gestational terminations performed in our clinic are compared to the early gestational terminations, we believe that conducting ultrasonographic anomaly screening to all pregnant women including echocardiography even at a less rate, and also making screening programs in the early gestational periods such as aneuploidy screening easily accessible for all pregnant women may help to maintain maternal health by decreasing the rates of the cases with late gestational termination.
\end{abstract}

Keywords: Gestational termination, prenatal screening, fetal structural anomaly.

\section{Özet: Erken ve geç gebelik terminasyonu olgularının değerlendirilmesi}

Amaç: Kliniğimizdeki gebelik terminasyonu uygulanan olguların incelenerek erken ve geç gebelik terminasyonu olgularının özelliklerinin araştırılması amaçlandı.

Yöntem: Ocak 2017 ile Aralık 2019 arasında tekil gebeliği olan ve fetal endikasyonlara bağlı gebelik terminasyonu uygulanan tüm gebeler çalışmaya dahil edildi.

Bulgular: Calışmaya 263'ü erken gebelik terminasyonu (Grup 1) ve 78 'i geç gebelik terminasyonu (Grup 2) olmak üzere 341 olgu dahil edildi. Grupların demografik özellikleri arasında fark izlenmedi. 341 olgunun 273'ünde (\%80.1) ultrasonografide yapısal anomali saptanırken, 68 (\% 19.9) olguda yapısal anomali izlenmedi. Yapısal anomali izlenen olguların 200'ünde (\%73) izole sistem anomalisi saptanırken, 73 olguda (\%26.7) çoklu sistem anomalisi bulundu. Olguların \%68'ine karyotip analizi uygulandı ve bunların \%52.6'sinda kromozom anomalisi saptandi. Karyotip analizi sonucu normal olan olgular arasında çoğunluğu talasemi olmak üzere 22 olguda tek gen hastalığı saptandı. Geç terminasyon olgularında yapısal anomali (\%91'e karşı \%76.8) sıklı̆̆ı anlamlı olarak yüksek saptanırken benzer şekilde izole kardiyovasküler anomali (\%37.5'e karşı \% 13.8) sıklı̆̆ da geç terminasyon olgularında anlamlı yüksekti. Terminasyon sonrası olguların \%16.7'sine otopsi uyguland 1 ve bunların \%86'sinda prenatal ultrasonografik bulgularla uyum izlenirken \%22.4 olguda otopside ek bulgu saptandi.

Sonuç: Kliniğimizde uygulanan geç gebelik terminasyonları erken gebelik terminasyonları ile kıyaslandığında daha az olmakla birlikte ekokardiyografinin dahil edildiği ultrasonografik anomali taramasının tüm gebelere uygulanması ve aynı zamanda anöploidi taraması gibi erken gebelik haftalarındaki tarama programlarının tüm gebeler için kolay ulaşılabilir kılınması geç gebelik terminasyonu olgularının daha da azalmasını sağlayarak maternal sağlı̆̆ın korunmasına katkı sağlayabilir.

Anahtar sözcükler: Gebelik terminasyonu, prenatal tarama, fetal yapisal anomali.

Correspondence: Serdar Kaya, MD. Department of Perinatology, Clinics of Gynecology and Obstetrics, Ba.cilar Training and Research Hospital, Health Sciences University, Istanbul, Turkey. e-mail: kayaserdar75@hotmail.com / Received: May 15, 2020; Accepted: June 4, 2020

Please cite this article as: Kaya S, Vaizoğlu F, Yakut Uzuner S, Toru HS, Şimşek M, Kumru S. The assessment of early and late gestational termination cases. Perinatal Journal 2020;28(2):82-88. doi:10.2399/prn.20.0282007

ORCID ID: S. Kaya 0000-0002-4092-7316; F. Vaizoğlu 0000-0002-0609-8454; S. Yakut Uzuner 0000-0002-9540-5099; 


\section{Introduction}

Fetal malformations have been an important issue in fetal medicine and become one of the significant reasons of perinatal deaths. ${ }^{[1]}$ The incidence of gestational termination associated with fetal malformation has been reported 5.2 per 10,000 live births and its incidence has been increasing. ${ }^{[2]}$ As the ultrasonographic anomaly screening performed in the second trimester of pregnancy has become prevalent, the rate of detecting fetal anomalies during prenatal period has increased. ${ }^{[3]}$ With the addition of ultrasonographic, biochemical and genetic examinations into the first trimester screening programs and the technological developments in ultrasound devices and equipment, diagnosing many fetal anomalies (structural, genetic, and chromosomal) during early weeks of gestation has become possible. Thus, it has been contributed to the maintenance of maternal health by conducting gestational termination during early weeks of gestation in necessary cases. ${ }^{[4-6]}$

The rights regarding gestational termination have been determined within the limits of the law, and they vary by countries. In Turkey (Law No 2827, 1983), voluntary gestational termination is allowed in the first 10 weeks of gestation while it is possible after 10 weeks of gestation only in the cases where the life of mother is endangered or in the presence of lethal diseases or severe disability which are incurable for the fetus, regardless of the week of gestation.

In our study, we evaluated the records of the cases which underwent gestational termination in our perinatology clinic. In addition to the indications of gestational termination, we assessed the characteristics of the early and late gestational termination cases to raise awareness regarding the early diagnosis of fetal structural, chromosomal and genetic anomalies during prenatal period.

\section{Methods}

In this study, we retrospectively evaluated 341 cases which underwent gestational termination for medical purposes in the Perinatology Clinic of the Faculty of Medicine at Akdeniz University between January 2017 and December 2019. The ethics committee approval was obtained from the Clinical Research Ethics Committee of the Faculty of Medicine of Akdeniz
University with the decision no. 70904504/544. All fetal ultrasonographic examinations were carried out by maternal-fetal medicine specialists by using Toshiba Applio 500 (Toshiba Medical Systems, Co., Ltd., Otawara, Japan) ultrasonography device. Karyotype analysis was offered to all cases who were found to have anomaly in the ultrasonographic examination or who were in the high risk group in the prenatal aneuploidy screening tests. After clinical evaluations of the cases were completed, the families were informed about potential fetal and postnatal prognosis by a board consisting of perinatology, medical genetic, pediatrics and relevant pediatric sub-specialty experts. In the presence of lethal anomalies and anomalies with the expectations of postnatal severe disability, the gestational termination was performed after informing families in detail and obtaining their consents. The terminations performed due to maternal indications and multiple pregnancies were excluded from the study.

The cases included in the study were categorized in two groups according to the week of gestation at which gestational termination was performed. The patients who underwent termination before 23 weeks of gestation were included in the Group 1 (early termination) while the patients who underwent termination at and after 23 weeks of gestation were included in Group 2 (late termination). The fetocide was performed in all late termination cases by administering intracardiac potassium chloride guided with ultrasonography before termination. Autopsy after termination was offered to all cases.

SPSS version 23 (Statistical Package for the Social Sciences; SPSS Inc., Chicago, IL, USA) was used for the statistical analysis of the data. The descriptive statistics were given as mean \pm standard deviation, median (minimum-maximum) and number (percentage). Normal distributions of continuous variables were tested by Kolmogorov-Smirnov test. The numerical variables not conforming normal distribution were compared by Mann-Whitney U test. Categorical variables were compared by chi-square test or Fisher's exact probability test between the groups. The statistical significance level was considered 0.05 .

\section{Results}

While 263 (77.1\%) of 341 cases, who were included in the study, underwent early gestational termination, 78 
Table 1. The demographic characteristics of the cases.

\begin{tabular}{lcccc} 
& $\begin{array}{c}\text { Group 1 } \\
(\mathbf{n = 2 6 3 )}\end{array}$ & $\begin{array}{c}\text { Group 2 } \\
(\mathbf{n = 7 8 )}\end{array}$ & $\begin{array}{c}\text { Total } \\
(\mathbf{n}=\mathbf{3 4 1})\end{array}$ & $\mathbf{p}$-value \\
\hline Age (year) & $31.2 \pm 6.5$ & $31.0 \pm 5.5$ & $31.1 \pm 6.3$ & 0.903 \\
\hline Gravida $(\mathrm{n})$ & $2(1-8)$ & $2(1-7)$ & $1(1-8)$ & 0.175 \\
\hline Parity $(\mathrm{n})$ & $1(0-3)$ & $1(0-3)$ & $1(0-3)$ & 0.306 \\
\hline Week of gestation at termination (week) & $16.7 \pm 2.7$ & $25.0 \pm 1.3$ & $18.6 \pm 4.2$ & $<0.001$ \\
\hline
\end{tabular}

The data are presented as mean \pm SD and median (minimum-maximum).

$(22.9 \%)$ cases underwent late gestational termination. Mean maternal age of the cases was 31.1 years and mean week of gestation during termination was 18.6 weeks. There was no significant difference between the groups in terms of maternal age, gravida, parity and abortion (p>0.05). The demographic characteristics of the cases are given in Table $\mathbf{1}$.

The structural anomaly was observed in 273 (80.1\%) of 341 cases, who were included in the study, in the ultrasonographic examination and no structural anomaly was observed in $68(19.9 \%)$ cases. While the structural anomaly incidence was $76.8 \%$ in the early termination cases, the structural anomaly was found in $91 \%$ of the late termination cases ultrasonographically $(\mathrm{p}=0.006)$. Of 273 cases found to have structural anomaly in the ultrasonographic examination, $200(73.3 \%)$ had isolated system anomaly and 73 (26.7\%) had multiple system anomaly. Isolated system anomaly was found in $75.2 \%$ of the early termination cases and in $67.6 \%$ of the late termination cases $(p>0.05)$. When the distribution of isolated anomalies was evaluated according to the systems, the incidence of isolated cardiovascular system anomaly was significantly higher in the late termination cases $(37.5 \%)$ compared to the early termination cases $(13.8 \%)$. The distribution of structural anomalies found in the cases according to the systems is shown in Table 2.

Karyotype analysis was performed in 232 (68\%) of 341 cases. Chromosomal anomaly was found in 122 $(52.6 \%)$ of the cases which underwent karyotype analysis. Twenty-two cases, of which $72.7 \%$ had thalassemia, had single gene disorder among 110 cases with normal karyotype analysis results. The karyotype analysis results of the cases are summarized in Table 3.

The autopsy was performed on 57 cases (16.7\%) after termination. In 49 (86\%) of these cases, autopsy findings were fully or partially consistent with the ultrasound findings while there were inconsistencies between the findings in $8(14 \%)$ cases. The additional findings were found in $11(22.4 \%)$ of the cases in which autopsy and prenatal findings were consistent.

\section{Discussion}

The congenital anomalies are the major reasons of infant deaths and $2 \%$ of the infants have congenital anomaly. ${ }^{[4]}$ Ultrasonographic fetal anomaly screening has been a significant tool for the prenatal diagnosis of congenital anomalies, it has made possible to detect most of the congenital anomalies prenatally. While the sensitivity of routine ultrasonographic screening for major anomalies is $74 \%$, it is $46 \%$ for minor anomalies. ${ }^{[7]}$ The rate of detecting fetal anomaly by ultrasonography varies according to the number and structure of anomalies, and the affected organ system. ${ }^{[4,8,9]}$ While the sensitivity of the ultrasonography has higher values with the rates of $83 \%$ in the major anomalies of central nervous system (CNS) and $85 \%$ in the major anomalies of urinary system, it is $38.8 \%$ in cardiovascular system (CVS) anomalies. ${ }^{[7]}$ With the contribution of technological developments in the devices in addition to the prevalent use of ultrasonography and screening tests to determine the risk of chromosomal anomaly in all pregnant women at early weeks of gestation, it has become possible to examine fetal anatomy in more detail and the progress has been made for the early diagnosis of chromosomal anomalies. ${ }^{[10]}$ Considering the elevation in the complications at the end of each completed week of gestation and additional burden for maternal emotional state caused by the gestational termination, performing the termination as early weeks of gestation as possible is important for the maternal health. ${ }^{[11-13]}$

Vaknin et al. performed gestational termination on 462 cases (328 early gestational termination cases and 134 late gestational termination cases) and found that the 
Table 2. The distribution of the structural anomalies of the cases according to the systems.

\begin{tabular}{|c|c|c|c|c|c|}
\hline Isolated system anomalies & & Group 1 & Group 2 & Total & p-value \\
\hline \multirow[t]{8}{*}{ Central nervous system } & Anencephaly & 21 & 0 & 21 & \\
\hline & Encephalocele & 10 & 1 & 11 & \\
\hline & Spina bifida & 16 & 6 & 22 & \\
\hline & Hydrocephaly & 5 & 4 & 9 & \\
\hline & Holoprosencephaly & 3 & 1 & 4 & \\
\hline & Agenesis of the corpus callosum & 2 & 5 & 7 & \\
\hline & Posterior fossa anomalies & 8 & 8 & 16 & \\
\hline & Total & 65 & 25 & $90(45 \%)$ & $0.258^{*}$ \\
\hline \multirow[t]{7}{*}{ Cardiovascular system } & Hypoplastic left heart syndrome & 4 & 3 & 7 & \\
\hline & AVSD & 5 & 3 & 8 & \\
\hline & VSD & 4 & 1 & 5 & \\
\hline & Conotruncal anomalies & 2 & 7 & 9 & \\
\hline & Valve anomalies & 3 & 1 & 4 & \\
\hline & Great artery anomalies & 3 & 3 & 6 & \\
\hline & Total & 21 & 18 & $39(19.5 \%)$ & $<0.001 *$ \\
\hline \multirow[t]{5}{*}{ Genitourinary system } & Hydronephrosis & 1 & 0 & 1 & \\
\hline & Renal agenesis & 5 & 0 & 5 & \\
\hline & Lower urinary tract obstruction & 4 & 1 & 5 & \\
\hline & Cystic dysplastic kidney & 3 & 2 & 5 & \\
\hline & Total & 13 & 3 & $16(8 \%)$ & $0.766^{\dagger}$ \\
\hline \multirow{3}{*}{$\begin{array}{l}\text { Gastrointestinal system and } \\
\text { abdominal wall }\end{array}$} & Body stalk anomaly & 4 & 0 & 4 & \\
\hline & Omphalocele & 2 & 0 & 2 & \\
\hline & Total & 6 & 0 & $6(3 \%)$ & $0.399^{\dagger}$ \\
\hline \multirow[t]{3}{*}{ Thorax } & Hydrothorax & 2 & 0 & 2 & \\
\hline & Diaphragmatic hernia & 2 & 0 & 2 & \\
\hline & Total & 4 & 0 & $4(2 \%)$ & $0.574^{\dagger}$ \\
\hline \multirow[t]{6}{*}{ Skeletal system } & Lethal skeletal dysplasia & 10 & 1 & 11 & \\
\hline & Pes equinovarus & 1 & 0 & 1 & \\
\hline & Arthrogryposis & 3 & 1 & 4 & \\
\hline & Kyphoscoliosis & 1 & 0 & 1 & \\
\hline & Sirenomelia & 1 & 0 & 1 & \\
\hline & Total & 16 & 2 & $18(9 \%)$ & $0.251^{\dagger}$ \\
\hline \multirow[t]{3}{*}{ Craniofacial } & Cleft lips/palates & 1 & 0 & 1 & \\
\hline & Midline defects & 1 & 0 & 1 & \\
\hline & Total & 2 & 0 & $2(1 \%)$ & $0.577^{\dagger}$ \\
\hline Cystic hygroma & & 20 & 0 & $20(10 \%)$ & $0.005^{\dagger}$ \\
\hline \multirow[t]{2}{*}{ Non-immune hydrops } & & 5 & 0 & $5(2.5 \%)$ & $0.340^{\dagger}$ \\
\hline & Total (isolated) & 152 & 48 & $200(100 \%)$ & \\
\hline \multicolumn{6}{|l|}{ Multiple system anomaly } \\
\hline & Total (multiple) & 50 & 23 & 73 & \\
\hline
\end{tabular}

AVSD: atrioventricular septal defect; VSD: ventricular septal defect. *Pearson's chi-square test; †Fisher's exact probability test. The data are presented as n (\%).

presence of fetal structural anomaly was significantly high in the late termination group (62\% vs. $54 \%)$ and fetal chromosomal and genetic diseases were significantly high in the early termination group (40\% vs. $29 \%){ }^{[14]}$ In another study involving 144 late termination cases, the authors found fetal structural anomaly incidence $63 \%$ and reported it as the most common indication in the late termination group. ${ }^{[15]}$

Similarly, we found structural anomaly ultrasonographically in $80.1 \%$ of 341 cases, which underwent ter- 
Table 3. The distribution of the genetic examination results of the cases.

\begin{tabular}{|c|c|c|c|c|}
\hline & & Group 1 & Group 2 & Total \\
\hline \multirow[t]{8}{*}{ Chromosomal anomalies } & Trisomy 21 & 60 & 7 & $67(54.9 \%)$ \\
\hline & Trisomy 18 & 14 & 3 & $17(13.9 \%)$ \\
\hline & Trisomy 13 & 2 & 1 & $3(2.5 \%)$ \\
\hline & $45, x$ & 9 & 2 & $11(9 \%)$ \\
\hline & Triploidy & 4 & 1 & $5(4.1 \%)$ \\
\hline & Other numerical chromosomal anomalies & 5 & 4 & $9(7.4 \%)$ \\
\hline & Structural chromosomal anomalies & 5 & 5 & $10(8.2 \%)$ \\
\hline & Total & 99 & 23 & $122(100 \%)$ \\
\hline Genetic diseases & Thalassemia and other single gene diseases & 19 & 3 & 22 \\
\hline
\end{tabular}

The data are presented as $n(\%)$.

mination, and did not find any finding in $19.9 \%$ in our study. The cases without structural anomaly were mostly the patients which underwent aneuploidy screening tests or invasive diagnostic tests due to family history of genetic disease and underwent termination at early weeks of gestation and therefore did not have optimum ultrasonographic anomaly screening. In this context, when we compared early termination cases due to the presence of structural anomaly and late termination cases, we found that the structural anomaly incidence was significantly high in late termination cases which underwent optimum ultrasonographic anomaly screening $(76.8 \%$ vs. $91 \%)$.

In the studies conducted in the same center, Çorbacioğlu et al. ${ }^{[16]}$ found CNS anomaly as the most common anomaly (52\%) in 498 termination cases and reported the incidence of the multiple system anomaly $10 \%$ while Aslan et al. ${ }^{[17]}$ found CNS as the most common anomaly with a rate of $58 \%$ and reported the incidence of the multiple system anomaly $8.4 \%$. Moreover, Tayyar et al. ${ }^{[18]}$ also found CNS anomaly as the most common anomaly with a rate of $45 \%$ in the cases which underwent late termination, and they reported multiple system anomaly $8 \%$ in their study, which was conducted in the same center as well. In our study, isolated anomalies were $73.3 \%$ of the structural anomalies while multiple system anomalies were $26.7 \%$ of them. CNS anomaly (45\%) was the most common isolated system anomaly while CVS anomaly $(19.5 \%)$ was the other most common isolated anomaly. Considering the multiple system anomalies, CNS and CVS were the most common accompanying systems. The higher rates of multiple system anomalies in our study than the literature can be associated with the addition of the multiple anomalies encountered in the chromosomal anomalies into the date.

When we compare the early termination cases and the late termination cases in our cases, we see that CNS anomalies are the most common anomaly in both groups followed by CVS anomalies. However, we found that CVS anomaly rates were significantly higher in the late termination cases. In consistence with the literature, we may associate it with the fact that the ultrasonographic diagnosis of the cardiac anomalies is established in later weeks. ${ }^{[19]}$

While Vaknin et al. ${ }^{[14]}$ reported the rates of chromosomal diseases in the cases which underwent termination $35 \%$ for the early terminations and $26 \%$ for the late terminations, Tayyar et al ${ }^{[18]}$ reported it $19 \%$ for the late the late terminations. Çorbacioğlu et al. ${ }^{[16]}$ compared the rates of chromosomal diseases in cases which underwent termination between 2002-2006 and 2007-2010, they found that the rates were significantly higher between 2007 and 2010 and associated it with the prevalent use of aneuploidy screening tests.

In our study, $68 \%$ of the cases underwent karyotype analysis, and we found chromosomal anomaly in 52.6\% of the cases which underwent karyotype analysis, and $35.8 \%$ of 341 termination cases consisted of chromosomal diseases. The distribution of chromosomal anomalies we found in our study was consistent with the literature, and trisomy 21 was the most common anomaly. ${ }^{[14,16,20]}$ The majority of the cases with normal karyotype results consisted of single gene diseases associated with thalassemia in particular, and single gene diseases were responsible for $6.5 \%$ of all terminations. The ter- 
mination rate associated with single gene diseases was the main termination rate in our study compared to the literature. ${ }^{[1,16]}$ We believe that this difference originates from the fact that the patients included in the study live in the Mediterranean Region and thalassemia incidence is high in this region. We found that the chromosomal anomaly rate was higher in the early termination cases compared to the late termination cases in consistence with the literature (37.6\% vs. 29.5$) ;{ }^{[14,17]}$ however, the difference was not statistically significant. It seems that this difference depends on whether the cases underwent early gestational termination involve the terminations performed due to chromosomal anomaly as a result of aneuploidy screening tests and being able to accomplish this process at earlier weeks of gestation.

The autopsy rate of 341 cases included in our study is $16.7 \%$, which is quite low. There is a significant reduction in the numbers of both adult autopsies and pediatric and fetal autopsies in 21 st century in the literature. ${ }^{[21]}$ While the increase of complicated methods is responsible for this reduction, the attitudes of clinical physicians and pathologists also have an impact. A reduction more than $50 \%$ in pediatric autopsies in our institution in the last 3 years is remarkable. While autopsy findings were fully or partially consistent with the ultrasound findings in our cases with a rate of $86 \%$, the rate of inconsistency was $14 \%$. Considering that there are also partial inconsistencies, the reduced number of autopsy for the detection of concurrent anomalies causes a serious data loss. Awareness on the importance of autopsy should be raised not only among the physicians but also the families. The increase of autopsy rates may help to obtain a significant amount of data which can change patient follow-up and management.

The low rates of autopsy after termination, low numbers of cases in the late termination group and also the retrospective design of the study are among the limitations of our study. The high karyotype analysis rates of the cases can be considered as the powerful aspect of our study.

\section{Conclusion}

The prenatal diagnosis of fetal anomalies can be established in the earlier weeks of gestation with a higher accuracy by the increase of the numbers of centers and personnel experienced in this field, making ultrasono- graphic anomaly screening and aneuploidy screening tests a routine practice in all pregnant women and also including advanced technology and new screening tests such as extracellular DNA into the program. In conclusion, early prenatal diagnosis and intervention would provide significant contributions in terms of maternal health.

Conflicts of Interest: No conflicts declared.

\section{References}

1. Petrini J, Damus K, Russell R, Poschman K, Davidoff MJ, Mattison D. Contribution of birth defects to infant mortality in the United States. Teratology 2002;66 Suppl 1:S3-6. [PubMed] [CrossRef]

2. Wyldes MP, Tonks AM. Termination of pregnancy for fetal anomaly: a population-based study 1995 to 2004. BJOG 2007; 114:639-42. [PubMed] [CrossRef]

3. Rydberg C, Tunón K. Detection of fetal abnormalities by second-trimester ultrasound screening in a non-selected population. Acta Obstet Gynecol Scand 2017;96:176-82. [PubMed] [CrossRef]

4. Boyd PA, Chamberlain P, Hicks NR. 6-year experience of prenatal diagnosis in an unselected population in Oxford, UK. Lancet 1998;352:1577-81. [PubMed] [CrossRef]

5. Saltvedt S, Almström H, Kublickas M, Valentin L, Grunewald C. Detection of malformations in chromosomally normal fetuses by routine ultrasound at 12 or 18 weeks of gestation a randomised controlled trial in 39,572 pregnancies. BJOG 2006;113:664-74. [PubMed] [CrossRef]

6. Romosan G, Henriksson E, Rylander A, Valentin L. Diagnostic performance of routine ultrasound screening for fetal abnormalities in an unselected Swedish population in 2000-2005. Ultrasound Obstet Gynecol 2009;34:526-33. [PubMed] [CrossRef]

7. Grandjean H, Larroque D, Levi S; The Eurofetus Team. Sensitivity of routine ultrasound screening of pregnancies in the Eurofetus database. Ann N Y Acad Sci 1998;847:118-24. [PubMed] [CrossRef]

8. Levi S. Ultrasound in prenatal diagnosis: polemics around routine ultrasound screening for second trimester fetal malformations. Prenat Diagn 2002;22:285-95. [PubMed] [CrossRef]

9. Carrera JM, Torrents M, Mortera C, Cusí V, Muñoz A. Routine prenatal ultrasound screening for fetal abnormalities: 22 years' experience. Ultrasound Obstet Gynecol 1995;5:1749. [PubMed] [CrossRef]

10. Boyd PA, Devigan C, Khoshnood B, Loane M, Garne E, Dolk H; EUROCAT Working Group. Survey of prenatal screening policies in Europe for structural malformations and chromosome anomalies, and their impact on detection and termination rates for neural tube defects and Down's syndrome. BJOG 2008;115:689-96. [PubMed] [CrossRef] 
11. Rossi AC, Prefumo F. Accuracy of ultrasonography at 11-14 weeks of gestation for detection of fetal structural anomalies: a systematic review. Obstet Gynecol 2013;122:1160-7. [PubMed] [CrossRef]

12. Allan LD. Cardiac anatomy screening: what is the best time for screening in pregnancy? Curr Opin Obstet Gynecol 2003;15: 143-6. [PubMed] [CrossRef]

13. Dugoff L. Ultrasound diagnosis of structural abnormalities in the first trimester. Prenat Diagn 2002;22:316-20. [PubMed] [CrossRef]

14. Vaknin Z, Ben-Ami I, Reish O, Herman A, Maymon R. Fetal abnormalities leading to termination of singleton pregnancy: the 7-year experience of a single medical center. Prenat Diagn 2006;26:938-43. [PubMed] [CrossRef]

15. Vaknin Z, Lahat Y, Barel O, Ben-Ami I, Reish O, Herman A, et al. Termination of pregnancy due to fetal abnormalities performed after 23 weeks' gestation: analysis of indications in 144 cases from a single medical center. Fetal Diagn Ther 2009;25: 291-6. [PubMed] [CrossRef]

16. Çorbacıoğlu A, Aslan H, Aydın S, Akbayır O, Ersan F, Alpay $\mathrm{V}$, et al. Trends in fetal indications for termination of pregnan- cy between 2002 and 2010 at a tertiary referral centre. J Turk Ger Gynecol Assoc 2012;13:85-90. [PubMed] [CrossRef]

17. Aslan H, Yildirim G, Ongut C, Ceylan Y. Termination of pregnancy for fetal anomaly. Int J Gynaecol Obstet 2007;99: 221-4. [PubMed] [CrossRef]

18. Tayyar A, Acar DK, Turhan U, Özköse ZG, Ekiz A, Gezdirici A, et al. Late terminations of pregnancy due to fetal abnormalities: an analysis of 229 cases. [Article in Turkish] İstanbul Kanuni Sultan Süleyman Tıp Dergisi 2018;10:12-7. [CrossRef]

19. Allan LD. Cardiac anatomy screening: what is the best time for screening in pregnancy? Curr Opin Obstet Gynecol 2003;15: 143-6. [PubMed] [CrossRef]

20. Yılmaz Baran Ş, Alemdaroğlu S, Doğan Durdağ G, Kalaycı H, Yılmaz Çelik Z. The analysis of the termination of pregnancies at and after ten weeks of gestation - a monocenter study. Perinatal Journal 2019;27:14-21. [CrossRef]

21. Royal College of Pathologists of Australasia Autopsy Working Party. The decline of the hospital autopsy: a safety and quality issue for healthcare in Australia. Med J Aust 2004;180:281-5. [PubMed] [CrossRef] 